\title{
Filosofia e Literatura no Illuminismo ALEMÃO: A QUESTÃO DA TOLERÂNCIA RELIGIOSA NO NATHAN DER WEISE, DE LESSING
}

Mario Videira ${ }^{1}$

RESUMO: O presente artigo aborda a questão da tolerância religiosa no Iluminismo alemão, por meio da análise e interpretação de trechos selecionados da peça Nathan der Weise (1779), de Lessing. Pretende-se mostrar que essa obra tem sua origem intimamente ligada ao debate teológico ("Fragmentenstreit") entre Lessing e o pastor Johann Melchior Goeze, de Hamburgo, podendo ser lida como uma reação e uma resposta às críticas e objeções deste último.

PALAVRAS-CHAVE: Lessing (1729-1781). Nathan. Tolerância Religiosa. Iluminismo. Fragmentenstreit.

\section{INTRODUÇÃo}

O presente artigo pretende abordar a relação entre filosofia e literatura no Iluminismo e, mais especificamente, a questão da tolerância religiosa na Alemanha, por meio de uma análise do trecho central - conhecido como "a parábola dos três anéis" - do terceiro ato de Nathan der Weise (Nathan, o sábio), a última peça escrita por Gotthold Ephraim Lessing (1729-1781), publicada em 1779 e estreada somente em 1783, dois anos após sua morte. Trata-se, sem dúvida, de uma das mais importantes obras do teatro alemão, tendo influenciado autores como Goethe e Schiller, e cuja atualidade é atestada pela sua presença constante nos palcos. Como bem observou o crítico Anatol Rosenfeld, essa peça, “[...] com seu translúcido jogo intelectual e sua linguagem clara, sagaz e

\footnotetext{
${ }^{1}$ Mário Videira é doutor em Filosofia pela Universidade de São Paulo e mestre em Musicologia pela Universidade Estadual Paulista. Atualmente, é professor e pesquisador do Departamento de Música da Escola de Comunicações e Artes da USP. É autor de O Romantismo e o Belo Musical (Ed. Unesp, 2006) e tradutor de Berg: o mestre da transição mínima, de T. W. Adorno (Ed. Unesp, 2010). Além disso, publicou diversos artigos sobre Estética e Filosofia da Música em revistas especializadas, tanto no Brasil como no exterior
} 
astuta, é um dos mais preciosos legados que o humanismo da Ilustração alemã deixou aos pósteros" (ROSENFELD, 1993, p. 211).

Quanto ao gênero, Lessing classifica essa obra como "ein dramatisches Gedicht" (um poema dramático). Essa designação de gênero aponta para a impossibilidade de se referir à peça segundo as nomenclaturas usuais: Nathan não se deixa classificar inteiramente nem como uma comédia, nem como uma tragédia, embora contenha elementos de ambas. ${ }^{2}$ Quanto às suas características formais, a peça chama a atenção por estar escrita em versos brancos $^{3}$, bastante empregados por Shakespeare, e que Lessing introduz no teatro alemão. Além disso, ele emprega frequentemente a alternância das falas de personagens diferentes no interior do mesmo verso, tornando mais intensa a dinâmica da peça. Também o uso das pausas é usado de maneira a enfatizar a hesitação e a reflexão das personagens.

A obra está articulada em cinco atos, e sua trama se passa na cidade de Jerusalém, na época das Cruzadas (1192): ou seja, ela se insere num contexto de guerras religiosas e está ambientada numa cidade em que as três religiões abraâmicas se encontravam reunidas.

A peça se inicia com o rico mercador judeu Nathan retornando de uma viagem de negócios. Ele é recebido pela criada Daja, que lhe conta que sua casa havia se incendiado e que Recha, sua filha de criação, fora salva da morte por um jovem Cavaleiro cristão, que, por sua vez - e devido ao fato de sua fisionomia lembrar muito um irmão do Sultão (desaparecido há muitos anos) -, havia sido poupado da pena de morte. Embora o cavaleiro se mostre extremamente antissemita ${ }^{4}$, Nathan o convence - por meio de hábeis argumentos - a visitar sua filha Recha, a fim de receber pessoalmente sua gratidão. Enquanto isso, o Sultão Saladin, preocupado com suas dificuldades econômicas decorrentes da guerra, convoca Nathan sob o pretexto de pôr à prova sua sabedoria. Saladin

${ }^{2}$ Por exemplo, o papel de Al-Hafi como tesoureiro do sultão ou os comentários irônicos de Nathan em relação à superstição de Daja são claramente cômicos, ao passo que o comportamento intolerante do Patriarca e o assassinato da esposa e dos filhos de Nathan são de caráter trágico.

${ }^{3}$ Lessing utiliza versos iâmbicos de cinco pés (pentâmetro iâmbico), ao invés dos alexandrinos (12 versos, tônica na $6^{\mathrm{a}}$ e na $12^{\mathrm{a}}$ sílabas), típicos da tragédia clássica francesa. A opção pelo verso iâmbico visa a dar maior naturalidade às falas, ao passo que o alexandrino francês se caracterizava por sua natureza empolada e mais retórica.

${ }^{4} \mathrm{O}$ antissemitismo do Cavaleiro se evidencia já a partir do fato de que ele, inicialmente, não trata Nathan pelo nome, mas o chama simplesmente de "judeu" (LESSING, 1993, II 5, p. 529 e 531 ). A esse respeito, ver também, p. ex., a fala do Cavaleiro no final da sexta cena do Primeiro Ato (LESSING, 1993, I 6, p. 513). 
lhe pergunta qual das religiões - judaica, islâmica ou cristã - ele acredita ser a verdadeira, esperando que a fidelidade de Nathan ao judaísmo lhe desse um pretexto para sequestrar seus bens. Mas Nathan percebe a armadilha e lhe dá uma resposta sob a forma de parábola. ${ }^{5}$ Surpreso e satisfeito com a resposta dada por Nathan à questão que lhe fora proposta, o Sultão pede que eles se tornem amigos. E ele fica ainda mais satisfeito, quando Nathan lhe oferece espontaneamente um empréstimo. Enquanto isso, o Cavaleiro cristão, vencendo seus preconceitos, acaba se apaixonando por Recha e deseja casar-se com ela. Nathan parece ter muitas reservas quanto a esse projeto de casamento, o que desperta no Cavaleiro a desconfiança de que isso se deveria ao fato de ambos professarem religiões distintas. Ao tomar conhecimento de que Recha é filha adotiva de Nathan e de que seus verdadeiros pais eram cristãos, o Cavaleiro decide consultar o Patriarca de Jerusalém. Embora o Cavaleiro apresente o problema de forma apenas hipotética, o Patriarca se mostra furioso e exige que lhe tragam esse judeu - o qual, segundo ele, seria culpado de educar uma criança cristã numa falsa religião - e afirma que a pena para esse crime de apostasia é a condenação à morte pela fogueira. Por sorte, um bom monge intercede, trazendo provas de que Recha é irmã do Cavaleiro cristão e que ambos são, na verdade, os filhos de Assad, o irmão desaparecido do Sultão, o qual havia se convertido ao Cristianismo (o que, mais uma vez, ilustra o estreito parentesco entre essas três religiões).

Este é, em linhas gerais, o percurso da peça. Agora, trata-se de tentar examinar como filosofia e literatura encontram-se aí articuladas. A esse propósito, caberia lembrar a observação precisa de Franklin de Mattos (2001, p. 97), segundo o qual um dos traços mais fascinantes do século XVIII seria justamente "[...] a inexistência de fronteiras precisas entre filosofia e literatura e, consequentemente, a multiplicidade de gêneros então praticada pelo filósofo". Mattos (2001, p. 97) ressalta ainda que o tratado ordenado e rigoroso deixa de ser o meio privilegiado de expressão filosófica e o filósofo se torna romancista, contista, homem de teatro. Se, na França, autores como Diderot, Rousseau ou Voltaire (para nomear apenas alguns), procuraram integrar essas formas de expressão - conto, romance, peça teatral - ao combate filosófico das Luzes, "[...] tornando-as flexíveis para esclarecer os homens [...], [e] fazê-

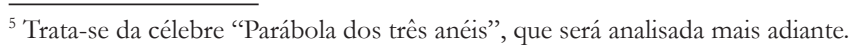


los virtuosos" (MATTOS, 2001, p. 98), pode-se dizer que, na Alemanha, um dos maiores representantes dessa tendência foi Gotthold Ephraim Lessing. ${ }^{6}$

Lessing é, geralmente, considerado como o grande reformador da literatura alemã, tendo dedicado grande parte de seus esforços às reflexões estéticas, à crítica de arte e à dramaturgia. ${ }^{7}$ Seus escritos influenciaram enormemente o pensamento estético e a produção dramática subsequente. Como bem observou Heinrich Heine, no livro Die romantische Schule [A Escola Romântica], Lessing foi aquele que libertou o teatro alemão da influência avassaladora da poesia clássica francesa. Nas palavras de Heine (1836, p. 31-34):

[Lessing] mostrou-nos a nulidade, o ridículo e a falta de gosto daquelas imitações do teatro francês que, por sua vez, parecia imitação do grego. Não somente através de suas críticas, mas também com suas próprias obras de arte, ele foi o fundador da nova e original literatura alemã.

Em 1770, Lessing aceita um emprego como bibliotecário, em Wolfenbüttel, na Biblioteca do Duque de Braunschweig. Após envolver-se numa disputa teológica com o Pastor Goeze, de Hamburgo, ele escreve sua última peça, Nathan der Weise (1779), vindo a falecer apenas dois anos depois, aos 52 anos de idade, na cidade de Braunschweig.

\section{A Controvérsia dos Fragmentos [Fragmentenstreit]}

Ainda no seu livro A Escola Romântica, Heinrich Heine (1836, p. 31-34) escreve que Lessing "[...] foi um paladino a serviço da liberdade de pensamento e contra a intolerância clerical". Para compreendermos essa afirmação, é preciso retomar ainda alguns pontos da biografia de Lessing. Três anos após assumir o posto de Bibliotecário em Wolfenbüttel, Lessing começa a editar as chamadas "Contribuições para a História e a Literatura" [Beiträge]. Uma vez que seu posto como bibliotecário ducal lhe permitia publicar seus

\footnotetext{
${ }^{6}$ Cf. HEGEL (2004, p. 222): “[...] em muitas épocas a poesia dramática, particularmente, também era utilizada para conquistar um acesso vivo a nossas representações da época, no que concerne à política, à eticidade, à poesia, à religião, etc. [...] Voltaire [...] procura com frequência divulgar seus princípios iluministas também por meio de obras dramáticas; sobretudo Lessing está empenhado, em seu Nathan, em justificar sua fé moral em oposição à ortodoxia limitadamente religiosa".

${ }^{7}$ Dentre suas principais obras dramáticas estão: Miss Sara Sampson (1755, considerada a primeira tragédia burguesa alemã), Minna von Barnhelm (1767), Emilia Galotti (1772) e Nathan der Weise (1779). Como crítico e teórico da estética, suas principais obras são a Dramaturgia de Hamburgo (1769) e o Laocoonte (1766). Além disso, escreveu inúmeros textos e artigos sobre filosofia e religião.
} 
textos, sem que tivesse que se submeter à censura, Lessing introduziu nessas coletâneas uma série de artigos extremamente críticos à ortodoxia religiosa, de autoria de seu amigo já falecido, Hermann Samuel Reimarus (1694-1768). ${ }^{8}$ $\mathrm{Na}$ tentativa de proteger a família de seu amigo, Lessing lança mão de um artifício para camuflar o verdadeiro autor e, entre os anos de 1774 a 1778, publica esses ensaios sob o título: "Fragmentos de um Autor Desconhecido" [Fragmente eines Unbekannten], como se fossem textos casualmente encontrados na coleção de manuscritos da biblioteca ducal. Esses manuscritos continham, grosso modo, uma crítica radical à Bíblia, questionando o seu caráter de Revelação Divina. Como observou Dieter Henrich (2003, p. 105, nota 7), "[...] esta obra submetia a revelação cristã ao escrutínio racional, baseandose em uma acurada crítica histórica". A publicação evocou fortes reações de refutação e desaprovação, marcando o início de uma querela que ficou conhecida como "Fragmentenstreit" [Controvérsia dos Fragmentos]".

Um texto datado de 1777 (ou seja, dois anos antes da publicação do Nathan), intitulado Sobre a prova do espirito e da força [Über den Beweis des Geistes und der Kraft], resume bastante bem a posição de Lessing na controvérsia: para ele, a vivência prática do Cristianismo (e especialmente a prática do amor ao próximo) seria mais importante que o apego aos dogmas da Bíblia.

Lessing defende que as verdades históricas não são totalmente confiáveis, pois consistem em relatos de segunda-mão, diferentes da experiência direta. Além disso, “[...] as verdades históricas não podem ser demonstradas" (LESSING, 1995, p. 92). Ora, uma vez que a autoridade das Escrituras se baseia, em última instância, nesse tipo de verdades, fica claro que elas são insuficientes para demonstrar a divindade dessas revelações: "Verdades contingentes da história [zufällige Geschichtswahrheiten] jamais podem se tornar a prova das verdades necessárias da razão [notwendigen Vernunftswahrheiten]” (LESSING, 1995, p. 92). Bastante célebre é sua

\footnotetext{
${ }^{8}$ Reimarus era um respeitado orientalista e autor de diversos livros sobre filosofia e religião natural. Como bem observou Dieter Henrich (2003, p. 105), os escritos de Reimarus refletem tanto a tradição do deísmo britânico (Toland, Tindal, entre outros), como também a crítica filológica da Bíblia feita na Alemanha, em sua época.

${ }^{9}$ Essa foi a maior controvérsia no Protestantismo alemão, durante o século XVIII. Além de numerosas recensões dos Fragmentos e das respostas de Lessing, foram publicados cerca de 50 livros e artigos sobre o assunto (Cf. LESSING, 2005, p. 8). 
imagem do "terrível e imenso abismo" entre as "verdades contingentes da história" e as "verdades necessárias da razão" (LESSING, 1995, p. 94).

Mas, por outro lado, como bem observou H. B. Nisbet (in LESSING, 2005, p. 12), “[...] a insistência no primado da ética [...] é uma característica constante nos escritos de Lessing". De fato, em vários de seus escritos, Lessing defende que a verdade do Cristianismo seria suficientemente demonstrada pelos seus frutos, isto é, por ser uma religião do amor: “[...] que me importa se as lendas são falsas ou verdadeiras; os frutos são excelentes" (LESSING, 1995, p. 95). De maneira significativa, Lessing encerra o artigo de 1777 [Über den Beweis des Geistes und der Kraff] com uma citação de um texto apócrifo, conhecido como o "Testamento de São João", no qual se afirma que as últimas palavras daquele apóstolo teriam sido: "Meus filhos, amai-vos uns aos outros".

A controvérsia iniciada com a publicação dos "Fragmentos" tornase ainda mais acirrada com a entrada do pastor Johann Melchior Goeze (1717-1786) no debate. Ao invés de atacar o autor anônimo, Goeze passa a atacar o editor dos manuscritos. Em linhas gerais, podemos dizer que o pastor Goeze defendia a importância dos relatos históricos da Bíblia e a verdade dos mesmos para a fé, afirmando ainda que a fé cristã não poderia subsistir se os conteúdos essenciais daquele texto sagrado fossem negados.

Num texto de 1778, intitulado "As fragilidades de Lessing" [Lessings Schwächen], o pastor Goeze (in LESSING, 1995, p. 96) exige que Lessing responda: "Qual religião ele próprio reconhece como verdadeira [wahre] e qual religião ele segue [annehme]"? Como veremos adiante, essa questão não difere muito daquela que será posta pelo sultão Saladin, e que Lessing responderá por meio da "Parábola dos três anéis", no Terceiro Ato de Nathan.

A controvérsia prolonga-se por meses, até que Goeze apela ao Duque de Brunswick e, em 3 de agosto de 1778, o governo determina o confisco de todos os exemplares dos "Beiträge", e os escritos de Lessing passam a ser censurados. Em 17 de agosto de 1778, o governo baixa a seguinte resolução: "[...] no que diz respeito aos temas religiosos, [Lessing] fica proibido de publicar qualquer coisa, seja aqui ou em outra parte, seja sob seu nome verdadeiro seja sob pseudônimo, sem a prévia autorização do Conselho de Ministros" (in LESSING, 1995, p. 99). 
Quando se torna impossível prosseguir a discussão - por conta da censura que lhe foi imposta - Lessing decide voltar ao "seu velho púlpito, ao teatro", e dali encerrar o debate com Goeze. ${ }^{10}$ É nesse contexto que ele decide escrever a peça Nathan der Weise.

\section{NATHAN E A QUESTÃO DA TOLERÂNCIA RELIGIOSA}

Podemos perceber, dessa forma, que o surgimento do Nathan está intimamente ligado à publicação desses "Fragmentos", extremamente críticos à religião cristã, bem como à controvérsia teológica daí resultante, entre Lessing e o pastor Goeze, de Hamburgo.

As cartas de Lessing a seu irmão Karl (agosto e outubro de 1778) e a Elise Reimarus (setembro de 1778) demonstram claramente que a decisão de escrever uma peça como o Nathan der Weise deve ser vista no contexto de uma continuação da controvérsia com os ortodoxos luteranos. ${ }^{11}$ Aliás, num esboço (não-publicado) para o prefácio de Nathan, Lessing (1995, p. 113) afirma: "As convicções de Nathan contra toda religião positiva foram, desde sempre, também as minhas". ${ }^{12}$ A partir dessa afirmação, torna-se mais clara a relação entre filosofia e literatura na última peça escrita por Lessing: como bem observou Yasukata (2002, p. 74), se quisermos compreender adequadamente a ideia de religião defendida por Lessing, é necessário levarmos em conta não apenas os textos específicos sobre esse assunto, mas também as ideias sobre religião expostas no Nathan.

\footnotetext{
${ }^{10}$ Numa carta a Elise Reimarus, datada de 06/09/1778, Lessing escreve: "Preciso tentar se pelo menos em meu velho púlpito, no teatro, ainda me permitirão pregar em paz" (in: LESSING, 1995, p. 101102).

${ }^{11}$ Em carta de 20/10/1778, endereçada a seu irmão Karl, Lessing escreve: "Será nada menos que uma peça satírica, para que eu possa deixar o campo de batalha com risos de sarcasmo" (in: LESSING, 1995, p. 102).

12 A respeito da noção de religião positiva, Hegel escreveu: "O conceito de positividade de uma religião somente surgiu e se tornou importante em épocas mais recentes; uma religião positiva é oposta à religião natural e com isto se pressupõe que exista somente uma religião natural, pois a natureza humana é apenas uma, e que, todavia, as religiões positivas podem ser muitas. Já a partir dessa oposição fica claro que uma religião positiva seria uma religião contranatural ou sobrenatural, que contém conceitos e noções que são exuberantes para o entendimento e a razão, que exige sentimentos e ações que não se deduziriam a partir do homem natural” (HEGEL, 1970, p. 216). 
De acordo com o próprio Lessing, o cerne a partir do qual a peça tem origem é a célebre "Parábola dos Três Anéis"13 - cujo argumento remonta à Idade Média, e tem uma de suas versões mais famosas no Decameron, de Boccaccio. Isso é documentado através de uma carta a seu irmão Karl (11/08/1778):

\begin{abstract}
Não quero que o conteúdo verdadeiro da minha peça seja conhecido cedo demais; mas se tu ou Moses [Mendelssohn] quiserem conhecê-lo, basta ler o Decameron, de Boccaccio (Giornata 1, Novella 3): O Judeu Melchisedech. Creio ter inventado um episódio muito interessante para ela, de modo que o todo resultará numa boa leitura, e que certamente irá irritar os teólogos mais do que com outros dez fragmentos. (in LESSING, 1995, p. 100).
\end{abstract}

Assim, convém examinar, de maneira mais detida, o diálogo entre Nathan e Saladin, que se encontra no Terceiro Ato do Nathan (Cenas 5-7), no qual essa célebre parábola se insere:

SALADIN - Já que és tão sábio, responda-me: qual é a fé, qual é a lei que mais te iluminou?

NATHAN — Sultão, eu sou um judeu!

SALADIN - E eu, um muçulmano. O cristão está entre nós. Dessas três religiões, só uma pode ser a verdadeira. - Um homem como você não permanece no lugar onde o acaso do nascimento o colocou; ou, se permanece, ele o faz em virtude de um exame [Einsicht], por razões [Gründen], por uma escolha do melhor. Pois bem! Então compartilha esse exame comigo. Diz-me as razões, a respeito das quais, por falta de tempo, eu não pude ainda meditar. Deixe-me conhecer - é claro, em sigilo - a escolha determinada por essas razões, para que eu possa fazê-las minhas. (LESSING, 1993 , p. 553, grifos nossos).

A frase que merece especial atenção aqui é "Um homem como você" - ou seja: um sábio - "não permanece no lugar onde o acaso do nascimento o colocou". A questão colocada pelo sultão é: quais foram as razõoes [Gründen] que determinaram a escolha de Nathan? Assim, a pergunta de Saladin diz respeito à justificativa da permanência de Nathan no judaísmo.

Nathan percebe a armadilha do Sultão: se ele respondesse, sem mais, que o judaísmo é a melhor das três religiões, ele ofenderia a religião do Sultão, que então poderia sequestrar seus bens, a título de reparação. Por

\footnotetext{
${ }^{13} \mathrm{Na}$ segunda parte de seus Cursos de Estética, Hegel faz referência à parábola narrada por Nathan, acentuando a necessidade de se interpretar a narrativa em vista de seu "conteúdo mais amplo", a saber, "[...] da diferença e da autenticidade das três religiões - a judaica, a maometana e a cristâ" (cf. HEGEL, 2000, p. 119).
} 
outro lado, se afirmasse que o islamismo é a melhor das três religiões, apenas para agradar ao Sultão, este poderia exigir que Nathan se convertesse. Além disso, na opinião do Sultão, Nathan estaria agindo de maneira irracional (e, portanto, incompatível a com atitude de um sábio), se admitisse permanecer no judaísmo sem nenhuma razão capaz de fundamentar tal escolha. Assim, a única saída é tentar se esquivar de uma resposta direta, o que Nathan consegue através de um artifício, de uma resposta indireta - ou melhor, por meio da narrativa de uma parábola:

SALADIN — Pois bem, fala! Não nos ouve uma só alma.

NATHAN — Queira Deus que o mundo inteiro nos ouça! [...] Permitame sultão, que eu lhe conte uma pequena história.

Há muitos e muitos anos, vivia no Oriente um homem que possuía um anel de valor incalculável, recebido de mão amada. A pedra era uma opala, que refletia cem belas cores e o anel possuía o poder secreto de tornar agradável a Deus e aos homens aquele que o usasse com essa confiança. [...] Esse homem decidiu conservar esse anel para sempre em sua família. Do seguinte modo: ele deixou o anel para o seu filho mais amado, e estabeleceu que este, por sua vez o deixasse ao mais amado, e assim por diante. E independente do nascimento, somente em virtude do anel, esse filho predileto se converteria no chefe da casa. [...] E assim foi, de filho em filho, até que se chegou a um pai que tinha três filhos, os quais ele amava igualmente. [...] Assim, ele teve a piedosa fraqueza de prometer o anel a cada um deles. Quando chegou a hora de sua morte, o bom pai se viu em dificuldades: como fazer para não magoar os outros dois filhos, sendo que ele amava igualmente aos três? Em segredo, ordenou que um artista fabricasse outros dois anéis iguais, absolutamente iguais ao primeiro. O artista conseguiu cumprir a encomenda. Nem mesmo o pai conseguia distinguir o original. Satisfeito, o pai chama cada um dos filhos em particular, dá a sua benção - e o anel - e morre. Está ouvindo, sultão? SALADIN — Sim, sim! Falta muito para acabar?

NATHAN — Já acabei. Pois o que se segue se entende por si só. - Mal faleceu o pai, cada um se apresentou com seu anel querendo ser o chefe da casa. Investiga-se, disputa-se, lamenta-se. Inútil: é impossível demonstrar qual é o verdadeiro anel;

(depois de uma pausa em que espera a resposta do Sultão)

Quase tão indemonstrável [unerveislich] como é para nós — a fé verdadeira [recbte Glaube]. (LESSING, 1993, p. 555-557).

O que Nathan parece afirmar é que, tal como ocorrera no caso dos anéis, seria impossível demonstrar racionalmente a verdade ou falsidade de uma religião. Saladin, percebendo o subterfúgio, pressiona Nathan por uma resposta: 
SALADIN — Como? É essa a resposta à minha pergunta?... [...] Os anéis! - Não brinque comigo! - Penso que as religiões que te indiquei podem muito bem ser distinguidas. Até pela vestimenta, pela comida, e pela bebida! (LESSING, 1993, p. 557)

O que está em jogo aqui e o que o personagem Nathan tentará demonstrar em seguida, é que essas diferenças são meramente exteriores e se apoiam sobre bases históricas, e que, portanto, nada têm a ver com uma possível fundamentação última da religião.

NATHAN - E somente no que diz respeito aos seus fundamentos [Gründe] elas não se distinguem. — Pois todas as três não estão baseadas sobre a história [Geschichte]? Escrita ou oralmente transmitida? E a história não deve ser aceita somente por confiança e fé? Não é? - Bem, qual é a confiança e a fé de que se duvida menos? Não é a daqueles que são do nosso sangue, que desde a nossa infância nos deram provas de seu amor e que não nos enganaram nunca? [...] Como é possível que eu creia nos meus pais menos do que tu acreditas nos teus? Ou o contrário. Posso exigir que acuses teus antepassados de mentirosos para que não contradigam aos meus? O mesmo vale para os cristãos. Ou não?

SALADIN - (Este homem tem razão. Tenho que me calar.) (LESSING, 1993, p. 557-58).

Uma importante questão filosófica está contida nessas palavras, e diz respeito aos fundamentos da pretensão à verdade das religiões positivas (ou sobre uma possibilidade de demonstração dessa verdade). A questão de Saladin, implicitamente, pressupõe que exista uma única religião verdadeira, e que essa verdade possa ser demonstrada em bases racionais, por meio de um exame capaz de fundamentar uma escolha, uma opção do homem sábio por uma das religiões positivas. No entanto, a resposta de Nathan vai no sentido diametralmente oposto: todas essas religiões podem ser distinguidas em todos os seus aspectos, exceto em seus fundamentos, “[...] pois todas estão fundadas na história". Assim como a autenticidade ou falsidade dos anéis não é objetivamente demonstrável, não há também nenhuma possibilidade de prova racional sobre qual das três religiões é a verdadeira.

Lembremos aqui da tese de Lessing, anteriormente mencionada, segundo a qual as verdades históricas não podem ser demonstradas: "Verdades contingentes da história [zufällige Geschichtswabrheiten] jamais podem se tornar verdades necessárias da razão [notwendigen Vernunftswahrbeiten]" (LESSING, 1995, p. 92). 
Assim, já que não é possível demonstrar racionalmente a verdade de uma religião - uma vez que ela se fundamenta em fatos históricos - qual seria o critério de decisão? Nathan retoma a narrativa da parábola:

\begin{abstract}
NATHAN - Voltemos a nossos anéis. Como tinha dito: os filhos queixaram-se em juízo e cada qual jurou diante do juiz ter recebido o anel diretamente das mãos de seu pai. [...] Este não poderia ter sido falso com ele - como suspeitar isso de um pai tão querido? - Não restando outra alternativa senão acusar seus irmãos de traidores e vingar-se deles.

SALADIN— Que fez o juiz, então? — Prossegue!

NATHAN - O juiz disse: [...] Pensais que estou aqui para resolver enigmas? [...] Mas... um momento: dizeis que o anel verdadeiro possui a força maravilhosa de tornar seu dono agradável a Deus e aos homens. Isso deve decidir! Vejamos: quem de vós é o mais amado pelos outros dois? Falai! Calai-vos? Os anéis só agem para dentro e não para fora? Cada um ama apenas a si mesmo? Então não passais de impostores ludibriados. [...] Se preferis minha sentença a meu conselho: ide-vos! - Mas meu conselho é: tomai a coisa tal qual ela é: cada qual recebeu o anel de seu pai, pois creia com segurança que seu anel é o verdadeiro. [...] Uma coisa é segura: o pai amava igualmente aos três, e não quis favorecer um em prejuízo dos outros. Pois bem! Cada um imite seu exemplo de amor incorruptível e livre de preconceitos! Que cada um se esforce por manifestar a força do anel. Que essa força venha em auxílio, com doçura, com cordial tolerância, com as boas obras e com a mais íntima submissão a Deus. (LESSING, 1993, p. 558-559).
\end{abstract}

Nessa parábola, pode-se interpretar a figura do pai como uma representação de Deus, e os três filhos, como sendo as três religiões citadas pelo Sultão (o judaísmo, o cristianismo e o islamismo). Assim como o pai ama igualmente os seus três filhos, também Deus ama igualmente essas três religiões que, no entanto, disputam e combatem entre si - cada uma pretendendo ser a verdadeira religião - ao invés de imitar o amor que o pai demonstrou para com eles.

Quanto à figura do juiz, podemos dizer que ele é um sábio, que conhece os limites da razão humana. Por isso, tudo o que ele pode fazer é “[...] dar um conselho, ao invés de um veredito": o critério para o julgamento deve ser buscado nos poderes mágicos do próprio anel. Todavia, segundo esse critério, nenhum dos três filhos preenche os requisitos para fazer com que o anel se revele por si, pois que estão lutando uns contra os outros. Assim como a autenticidade do anel só poderá ser demonstrada pelo efeito do mesmo, também a verdadeira religião irá se mostrar não por meio da aparência exterior: não é pelas roupas, 
pelo culto, pelos dogmas, mas sim, pelos seus efeitos práticos, isto é, pela conduta moral de seus seguidores. ${ }^{14}$

Essa parábola reflete claramente a posição de Lessing em sua controvérsia com Goeze. Contra a opinião de que a verdade de cada religião seria demonstrável por via racional ou que ela poderia se justificar a partir de sua fundamentação em verdades contingentes da história, Lessing parece afirmar que isso não é possível, e que em última instância, é a ação moral que decide sobre a verdade da religião (cf. ROBERTSON, 2002, p. 42) $\cdot{ }^{15}$ Contra a pressuposição de que apenas uma única religião seria verdadeira, Lessing irá argumentar que a verdadeira religião

[...] é aquela que transcende todas as religiões históricas [religiões positivas] e que, não obstante, subjaz à verdade de cada uma delas. É uma religião baseada numa humanidade real e universal. Tal religião [...] une as pessoas numa comunidade. Numa palavra, é a "religião da humanidade" de Lessing. (YASUKATA, 2002, p. 81).

Nos dois atos seguintes, Lessing exemplifica, através do diálogo entre o Cavaleiro e o Patriarca, os perigos da intolerância dogmática, que não demonstra o amor ao próximo em suas ações. A isso se contrapõe o exemplo do próprio Nathan, que põe em prática a máxima cristã: "amai os vossos inimigos".

Isto se revela de modo bastante claro, por exemplo, no quarto ato da peça, quando o cavaleiro vai consultar o Patriarca sobre o caso de Recha, após ter sido informado que esta não era filha legítima de Nathan, mas sim filha adotiva:

CAVALEIRO — Suponhamos, reverendíssimo padre, que um judeu tem um filho único - ou melhor, uma filha - a quem educa com o maior esmero, a quem ama mais que a si mesmo, e a qual lhe corresponde com o amor filial. Suponhamos agora que se descubra que tal garota não é filha

\footnotetext{
${ }^{14}$ Cabe assinalar a similaridade entre o pensamento de Lessing e o de Spinoza a esse respeito. Com efeito, no Cap. XVI do Tratado Teológico-Político, Spinoza (2003, p. 221) escreve: "Como tínhamos demonstrado, a fé não exige tanto a verdade quanto a piedade [...]. Não é, portanto, quem apresenta os melhores argumentos que necessariamente demonstra a maior fé, mas sim quem apresenta as melhores obras de justiça e de caridade. E quão salutar e necessária não será uma tal doutrina para a sociedade, se queremos que os homens vivam em paz e concórdia!".

${ }^{15}$ Como bem afirmou Robertson (2002, p. 43), “[...] a verdade interior de cada religião é a sua incitação à ação moral. A tradição (o conteúdo histórico da religião) não pode estabelecer nenhuma verdade religiosa, pois cada um acredita na religião em que cresceu".
} 
do judeu: ele a recolheu quando menina, a comprou, a furtou - como quiserdes, e que essa menina é filha de cristãos e batizada, mas o judeu a educou como judia. Diz-me, reverendíssimo padre, o que fazer nesse caso? (LESSING, 1993, p. 576-577).

O Patriarca fica horrorizado com o caso narrado pelo Cavaleiro e afirma que se deveria executar imediatamente o que estabelecem o direito papal e o direito imperial como punição para “[...] tal sacrilégio, tal depravação", a saber: "ao judeu que induz um cristão à apostasia, [...] as leis ordenam a fogueira" (LESSING, 1993, p. 578). O cavaleiro pergunta: “[...] mas e se a criança tivesse morrido na miséria, se o judeu não tivesse se apiedado dela?”. A resposta do Patriarca: "Não faz mal! O judeu será queimado! Pois seria melhor que a criança tivesse morrido na miséria, do que ser condenada à danação eterna".

Quando o cavaleiro argumenta: "Mas dizem que ele educou a criança não propriamente em uma fé, mas à margem de toda fé, ensinando-a acerca de Deus nem mais nem menos do que aquilo que satisfaz à razão". A resposta do Patriarca é irredutível: "Não faz mal! O judeu será queimado! Aliás, mereceria que o queimassem três vezes! Como? Deixar uma criança crescer desprovida de fé? [...] Diga-me quem é esse judeu. Traga-o aqui” (LESSING, 1993, p. 578-79).

Assim como para Goeze, também para o Patriarca a fé cristã é claramente a fé verdadeira, o que justificaria - em última instância - o assassinato do judeu que conduziu a criança a uma religião supostamente falsa. Sua frase, seguidamente repetida, mostra o ânimo inquisitório do patriarca, e como sua ação está longe do ideal cristão de amor ao próximo. Além disso, entra em jogo, aqui, a ligação entre o trono e o altar, ou seja, da ligação entre teologia e política" , quando o Patriarca afirma que "[...] a ausência de crença é a mais perigosa para o trono. Todos os laços civis são desfeitos, dilacerados, se o homem não tem mais fé. Fora! Fora com tal sacrilégio!” Também aqui

\footnotetext{
${ }^{16}$ Não podemos deixar de mencionar, novamente, uma similaridade com o pensamento de Spinoza, principalmente no que diz respeito às suas reflexões sobre a ligação entre teologia e política. No "Prefácio" ao Tratado Teológico-Político, por exemplo, Spinoza (2003, p. 8) afirma: "E no que diz respeito aos conflitos desencadeados a pretexto da religião, é evidente que eles surgem unicamente porque se estabelecem leis que concernem matéria de especulação e porque as opiniões são consideradas crime e, como tal, condenadas. Os seus defensores e prosélitos são, por isso, imolados, não ao bem público, mas apenas ao ódio e à crueldade dos adversários". A respeito da relação entre Lessing e Spinoza, ver também GOETSCHEL (2004, p. 183-250) e HENRICH (2003, p. 104-109).
} 
podemos perceber uma alusão à controvérsia com Goeze (e ao fato de este último ter recorrido ao governo, para que Lessing fosse censurado).

Nesse mesmo ato, porém (Ato IV, Cena 7), o espectador fica sabendo da verdadeira história da adoção de Recha: o sábio judeu confessa ao monge que pouco antes de ele chegar, trazendo a pequena Recha para que Nathan a criasse, toda a sua família (mulher e sete filhos) havia sido brutalmente assassinada pelos cristãos:

\begin{abstract}
NATHAN - Alguns dias antes os cristãos haviam matado todos os judeus com suas mulheres e filhos; entre eles encontrava-se minha mulher com sete filhos [...], que morreriam todos juntos na casa de meu irmão, para onde os enviara a fim de que se refugiassem. [...] Quando chegaste, fazia três dias e três noites que eu estava prostrado diante de Deus, coberto de pó e cinzas, chorando [...] encolerizado, furioso, maldizendo a mim e ao mundo, jurando ódio irreconciliável à Cristandade. [...] Mas aos poucos voltou-me a razão. E falei com voz suave: E não obstante existe um Deus! Não obstante também isto foi um decreto divino! Pois bem! Ponha em prática o que compreendeste há tempos [...] (LESSING, 1993, p. 596, grifos nossos).
\end{abstract}

Ao ouvir esse relato, o monge exclama: "Nathan, Nathan! Por Deus! Tu és um cristão! Jamais houve um cristão melhor!" Ao que ele responde: "Pois o que me torna cristão aos teus olhos, é o mesmo que me torna judeu aos meus! [...] Aqui o que falta é agir! E foi o amor aos meus sete filhos que me uniu imediatamente à filha de outrem" - a saber: à filha de um cristão (LESSING, 1993, p. 597).

\title{
4. Considerações Finais
}

Na peça Nathan, o sábio, Lessing prossegue seu propósito iluminista de combate à superstição e à intolerância religiosa. Prosseguindo sua argumentação exposta nos escritos da "Controvérsia dos Fragmentos", ele procura indicar a diferença entre verdades da razão e verdades históricas, sublinhando que a evidência histórica nunca é completamente confiável; sempre é possível haver falsificação - e que não há acesso cognitivo à verdade religiosa. Como bem observou Ernst Cassirer:

Os valores intelectuais puros são [...] sentidos [aqui] como insuficientes. A verdade da religião não pode ser estabelecida segundo critérios puramente teóricos: não se pode decidir sobre o seu valor pondo de lado a sua eficácia moral. É esse o significado em Lessing da parábola do anel: a 
verdade última e profunda da religião só se prova desde o interior. Toda demonstração extrínseca é insuficiente, quer se trate de uma demonstração empírica, apoiando-se em fatos históricos, ou de uma demonstração lógico-metafísica, escorada em razões abstratas, visto que, em definitivo, a religião é sempre e tão somente o que age; a verdade de sua essência só se realiza no sentido e na ação. (CASSIRER, 1992, p. 230-31).

Dessa forma, Lessing apela à ação moral como critério da verdade religiosa, opondo a ortodoxia do Patriarca (que pretende exercer o controle sobre a opinião e o pensamento dos fiéis) à ortopraxia de Nathan (que procede segundo regras corretas do agir, a saber: piedade, caridade e amor ao próximo).

Como apontamos anteriormente, é possível identificar alguns pontos de concordância entre o pensamento de Lessing e Spinoza. ${ }^{17}$ No Cap. XVI do Tratado Teológico-Politico, por exemplo, Spinoza afirma: "[...] toda a lei consiste unicamente em amar o próximo. [...] Tal mandamento é, portanto, o único critério de toda a fé católica e só em função dele devem ser determinados todos os dogmas da fé" (SPINOZA, 2003, p. 216, grifos nossos). No "Prefácio" dessa mesma obra, lemos ainda:

\begin{abstract}
Inúmeras vezes fiquei espantado por ver homens que se orgulham de professar a religião cristã, ou seja, o amor, a alegria, a paz, a continência e a lealdade para com todos, combaterem-se com tal ferocidade e manifestarem cotidianamente uns para com os outros um ódio tão exacerbado que se torna mais fácil reconhecer a sua fé por estes do que por aqueles sentimentos. De fato, há muito que as coisas chegaram a um ponto tal que é quase impossível saber se alguém é cristão, turco, judeu ou pagão, a não ser pelo seu vestuário, pelo culto que pratica, por freqüentar esta ou aquela igreja, ou, finalmente, porque perfilha esta ou aquela opinião e costuma jurar pelas palavras deste ou daquele mestre. (SPINOZA, 2003, p. 9).
\end{abstract}

À intolerância, baseada na ilusão de que a própria fé é a única verdadeira, e que, portanto, seria legítimo combater - e até mesmo matar - em nome dessa fé, a essa “" [...] competição que opõe as diversas religiões históricas, pois cada uma delas reivindica só para si uma superioridade absoluta que redunda na rejeição dogmática de todas as outras crenças" (CASSIRER, 1992, p.

\footnotetext{
${ }^{17}$ Para Willi Goetschel, tanto a Ética como o Tratado Teológico-Politico de Spinoza funcionam como uma espécie de "subtexto" ao Nathan, de Lessing. Para o autor, "[...] Nathan defende precisamente a distinção entre religião e superstição feita por Spinoza [...]. Sua religiosidade consiste em um tipo de sabedoria de caráter espinosista, emancipadora e orientada para a práxis. (GOETSCHEL, 2004, p. 236-37).
} 
231), Lessing opõe um ideal de humanismo, segundo o qual o valor do homem não depende de sua crença religiosa, mas sim de suas ações. E o personagem Nathan encarna esse ideal humano de maneira exemplar: mesmo tendo sua esposa e sete filhos queimados pelos cristãos, ele põe em prática o preceito de amar aos seus inimigos, não apenas aceitando adotar Recha, filha de cristãos, porém, criando-a com o mesmo amor que dedicaria a uma filha natural. Por outro lado, como se pôde notar, o Patriarca é a personificação da intolerância: “Tut' nichts! Der Jude wird verbrannt!" [Não faz mal! O judeu será queimado].

Como se vê, o ideal de humanismo de Nathan acaba por transcender as religiões particulares. ${ }^{18} \mathrm{O}$ mais importante é a eficácia da ação moral, tal como pregada no "Testamento de São João", anteriormente mencionado: "Meus filhos, amai-vos uns aos outros".

Por fim, cabe assinalar que os pontos principais do pensamento de Lessing sobre a religião, expostos em sua última peça teatral, já estavam presentes numa carta endereçada a seu pai, cerca de trinta anos antes da publicação do Nathan. A carta é datada de 30 de maio de 1749, e mantém sua atualidade ainda nos dias de hoje:

O tempo irá dizer se o melhor cristão é aquele que sabe de memória os princípios do ensinamento cristão e que os tem na ponta da língua - muitas vezes, sem compreendê-los -, que vai à igreja e segue todos os costumes porque está habituado a eles; ou se o melhor cristão é aquele que teve sérias dúvidas e, após examiná-las, atingiu a convicção, ou pelo menos, está ainda tentando atingi-la. A religião cristã não é algo que deve ser engolido cegamente e adotado de boa fé por intermédio de nossos pais. Muitos de nós simplesmente herdamos deles [a religião], assim como herdamos suas posses. Mas nossos pais também mostram, através de sua conduta, que tipo de cristãos eles são. Enquanto eu observar que o mais importante mandamento cristão - "amai ao vosso inimigo" - continua sendo observado da maneira como o vemos atualmente, eu irei duvidar se aquelas pessoas que se dizem cristãs realmente o são. (LESSING apud YASUKATA, 2002, p. 16).

\footnotetext{
${ }^{18} \mathrm{Na} 6^{a}$ Cena do Ato II, por exemplo, Nathan afirma: "Nós não escolhemos nosso povo. Será que nós somos o nosso povo? [...] Será que cristãos e judeus são antes judeus e cristãos do que... seres humanos?" (LESSING, 1993, p. 533).
} 
VIDEIRA, Mario. Filosofia e Literatura no Iluminismo alemão: a questão da tolerância religiosa no Nathan der Weise, de Lessing. Trans/Form/Ação, (Marília); v.34, p.57-74, 2011, Edição Especial 2.

ABSTRACT: This article addresses the issue of religious tolerance in the German Enlightenment through the analysis and interpretation of selected excerpts of Lessing's Nathan der Weise (1779). It aims to point out that the origins of this play are closely related to the theological debate ("Fragmentenstreit") between Lessing and Johann Melchior Goeze (chief pastor of the Church of St. Catharine in Hamburg), therefore making the play possible to be read as a reaction and a response to the criticisms and objections of the latter.

KEYWORDS: Lessing (1729-1781). Nathan. Religious Tolerance. Enlightenment. Fragmentenstreit.

\section{REFERÊNCIAS}

BOCCACCIO, Giovanni. Decameron. Milano: Mondadori, 2009.

CASSIRER, Ernst. A filosofia do Iluminismo. Trad. A. Cabral. Campinas: Ed. UNICAMP, 1992.

GOETSCHEL, Willi. Spinoza's Modernity: Mendelssohn, Lessing, Heine. Wisconsin: University of Wisconsin Press, 2004.

HEGEL, Georg W. F. Cursos de Estética II. Trad. Marco A. Werle e Oliver Tolle. São Paulo: EDUSP, 2000.

. Cursos de Estética IV. Trad. Marco A. Werle e Oliver Tolle. São Paulo: EDUSP, 2004.

. Die Positivität der christlichen Religion. Neufassung des Anfangs (1800). In: Frübe Schriften. Frankfurt a.M.; Suhrkamp, 1970.

HEINE, Heinrich. Die romantische Schule. Hamburg: Hoffmann und Campe, 1836.

HENRICH, Dieter. Between Kant and Hegel: Lectures on German Idealism. Edited by David S. Pacini. Cambridge, MA: Harvard University Press, 2003.

LESSING, Gotthold E. De teatro e literatura. Trad. A. Rosenfeld. São Paulo: EPU, 1992. Bibliothek).

Lessings "Nathan der Weise". Stuttgart: Reclam, 1995 (Reclams Universal . Philosophical and theological writings. Ed. H. B. Nisbet. Cambridge: Cambridge University Press, 2005. 
Werke (1778-1780): Theologie-Kritische Schriften II. Hrsg. K. Bohnen, A.

Schilson. Frankfurt a.M.: Deutscher Klassiker Verlag, 1993.

MATTOS, Franklin de. O filósofo e o comediane. Belo Horizonte: Editora UFMG, 2001.

ROBERTSON, Ritchie. The Jewish question in German Literature 1749-1939. New York: Oxford University Press, 2002.

ROSENFELD, Anatol. História da literatura e do teatro alemães. São Paulo: Perspectiva, 1993.

SPINOZA, Baruch de. Tratado Teológico-Politico. Trad. D. P. Aurélio. São Paulo: Martins Fontes, 2003.

YASUKATA, Toshimasa. Lessing's Philosophy of Religion and the German Enlightenment. New York: Oxford University Press, 2002. 